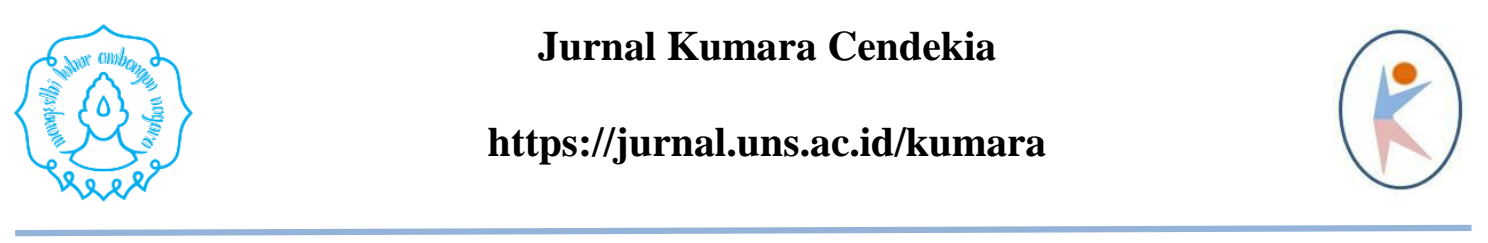

\title{
UPAYA MENINGKATKAN SELF CONFIDENCE MELALUI METODE TOKEN ECONOMY PADA ANAK USIA 5-6 TAHUN
}

\author{
Rahma Triastuti ${ }^{1}$, Drs. Hadi Mulyono, M.Pd ${ }^{2}$, Warananingtyas Palupi, S.Sn, M.A ${ }^{1}$ \\ $\mathbf{1}_{\text {Program Studi PG-PAUD, Universitas Sebelas Maret }}$ \\ $\mathbf{2}$ Program Studi PGSD, Universitas Sebelas Maret \\ E-mail: rahma.triastuti27@gmail.com, hadimulyono@yahoo.co.id, \\ palupi@fkip.uns.ac.id
}

ABSTRAK

Percaya diri merupakan modal dasar untuk pengembangan kemampuan diri yang dapat menjadikan anak mampu mengenal dan memahami diri sendiri. Kurang percaya diri dapat menghambat pengembangan potensi diri yang dimiliki anak. Metode token economy dinilai efektif sebagai sarana untuk mengelola perilaku anak di sekolah yang bertindak dan melayani kemudian memberikan imbalan untuk perilaku tertentu yang telah ditargetkan. Penelitian ini bertujuan untuk meningkatkan percaya diri anak usia 5-6 tahun di TK Marsudisiwi Jajar Surakarta tahun ajaran 2017/2018 dengan menggunakan metode token economy. Penelitian ini merupakan penelitian tindakan kelas (PTK) dengan pendekatan kuantiattif dan kualitatif. Subjek penelitian ini adalah anak usia 5-6 tahun TK Marsudisiwi Jajar Surakarta tahun ajaran 2017/2018. Hasil penelitian menunjukan bahwa penggunann metode token economy dalam pembelajaran dapat meningkatkan percaya diri anak. Peningkatan percaya diri diukur dari evaluasi pra tindakan, siklus I dan siklus II. Peningkatan percaya diri menggunakan metode token economy dapat dilihat dari peningkatan rata- rata klasikal dalam penilaian anak pada pra tindakan sebanyak 4 anak dengan persentase $28.57 \%$ kemudian pada siklus pertama meningkat menjadi 8 anak dengan persentase $57.14 \%$ dan pada siklus kedua meningkat menjadi 12 anak dengan persentase $85.71 \%$. Berdasarkan hasil penelitian, dapat disimpulkan bahwa penerapan metode token economy dapat meningkatkan percaya diri anak usia 5-6 tahun di TK Marsudisiwi Jajar Surakarta tahun ajaran 2017/2018.

Kata Kunci: Percaya diri, Token economy, Anak usia 5-6 tahun

\begin{abstract}
Confidence is the basis for the development of abilities that can make children able to recognize and understand themselves. Lack of confidence is a barrier to the development of children's self-potential. Token economy method is considered effective as a means to manage the behavior of children in schools who act and serve then provide rewards for certain behaviors that have been targeted. This research aims to increase the self confidence of children aged 5-6 years by using the token economy method at TK Marsudisiwi Jajar Surakarta in the academic year 2017/2018. This research is a classroom action research with quantitative and qualitative approaches. The subjects of this research was children 5-6 years old at TK Marsudisiwi Jajar Surakarta 2017/2018 academic year. The results of the research show that the
\end{abstract}


KUMARA CENDEKIA Vol. 7 No. 3 September 2019

use of the token economy method in learning can improve children's self confidence. Increased of self confidence is measured from pre-action evaluation, cycle I and cycle II. The increase in confidence that results from the implementation of the token economy method can be shown that the increase in classical average in the assessment of children in the pre cycle is 4 children with a percentage of $28.57 \%$ then in the first cycle increases to 8 children with a percentage of $57.14 \%$ and in the second cycle increases to 12 children with $85.71 \%$ percentage. Based on the results of the research, it was concluded that the implementation of token economy method has increased the confidence of children aged 5-6 years at TK Marsudisiwi Jajar Surakarta in the academic year 2017/2018.

Keywords: Self confidence, Token economy, Children 5-6 years old. 


\section{PENDAHULUAN}

Perkembangan aspek sosial emosional yang diharapkan pada anak usia dini ialah perilaku-perilaku yang baik, salah satu perilaku tersebut adalah percaya diri. Self Confidence atau percaya diri merupakan hal yang wajib dimiliki oleh seorang anak. Percaya diri dapat mempengaruhi perkembangan mental dan karekter anak. Mental dan karakter anak yang kuat dan stabil akan menjadi fondasi bagi masa depan anak, dengan hal tersebut anak mampu merespon setiap tantangan dengan lebih realistis (Rahayu, 2013). Percaya diri (self confidence) anak yang kurang berkembang dan tidak segera ditangani dapat mempengaruhi perkembangan pada aspek lainnya, sehingga akan menjadi dampak buruk untuk selanjutnya dalam tahapan perkembangan anak. Anak akan memiliki rasa malu yang berlebihan dan bahkan anak akan cenderung mengembangkan sikap rendah diri yang merasa bahwa dirinya tidak layak bersanding dengan orang lain, bersikap pesimis, bahkan menjadi orang yang dramatis dalam menanggapi berbagi kejadian dalam hidupnya kelak (Al-Hebaish, 2012).
KUMARA CENDEKIA Vol. 7 No. 3 September 2019

Melihat hal tersebut, setelah peneliti melakukan observasi awal pada anak kelas B TK Marsudisiwi Jajar diketahui bahwa percaya diri anak masih kurang. Hal ini dapat dilihat dari anak yang belum berani maju kedepan kelas untuk menujukan bakat atau hasil kerjanya, masih pasif, tidak percaya dengan kemampuan diri dan selalu menunggu bantuan dari guru atau teman.

Berdasarkan hasil observasi awal yang menunjukkan bahwa percaya diri anak kelas B masih perlu ditingkatkan, maka dalam upaya peningkatan tersebut penerapan metode token economy dapat menjadi alternatif untuk meningkatkan percaya diri anak karena metode ini dapat meningkatkan percaya diri anak melalui pemberian token yang nantinya dapat tukar dengan reward sehingga menumbuhkan motivasi bagi anak hingga percaya diri tersebut akan terbentuk dalam diri anak seiring dengan pelaksanaan metode ini.

Rumusan masalah dalam penelitian ini adalah apakah metode token economy dapat meningkatkan percaya diri pada anak kelas B TK Marsudisiwi dan tujuan penelitian ini adalah untuk meningkatkan 
percaya diri anak usia 5-6 tahun melalui

metode token economy.

\section{Percaya Diri}

Self Confidence atau percaya diri merupakan kemampuan seseorang untuk dapat memahami dan meyakini seluruh potensi yang ia miliki agar dapat dipergunakan dalam menghadapi penyesuaian diri dengan lingkungan hidupnya. Percaya diri akan membuat anak merasa yakin bahwa dirinya memiliki potensi untuk melakukan suatu tindakan dalam rangka menghadapi penyesuaian diri di lingkungannya (Dariyo, 2007). Kepercayaan diri menurut Santrock (2003) mendefinisikan bahwa kepercayaan diri sebagai suatu dimensi evaluatif yang menyeluruh dari diri seseorang. Percaya diri juga disebut sebagai harga diri atau gambaran diri.

Percaya diri yang di jelaskan oleh Dirjen PAUDNI (2012) merupakan sikap yang menunjukan bahwa anak memahami tentang kemampuan diri dan nilai harga dirinya. Hal ini dapat diartikan bahwa percaya diri anak akan muncul saat anak dapat memahami dirinya sendiri serta melakukan sesuatu hal yang sesuai dengan nilai harga diri yang dimilikinya. Pendapat ini sejalan dengan Lauser (2006), kepercayaan diri merupakan suatu sikap atau keyakinan atas kemampuan diri sendiri sehingga dalam tindakan - tindakannya seseorang yang bersangkutan tidak cemas, merasa bebas untuk malakukan hal-hal yang sesuai keinginan dan tanggung jawab atas perbuatanya, sopan dalam berinteraksi dengan orang lain, memiliki dorongan prestasi serta dapat mengenal kelebihan dan kekurangan diri sendiri. Sedangkan orang yang mempuanyai kepercayaan diri memiliki ciri-ciri tidak mementingkan diri sendiri (toleransi), tidak membutuhkan dorongan orang lain, optimis dan gembira.

Menurut Angelis (Rahayu, 2013), kepercayaan diri merupakan hal yang dengannya anak mampu menyalurkan segala sesuatu yang diketahuinya dan dikerjakannya, sebagai sikap positif untuk mengembangkan penilaian positif terhadap dirinya maupun lingkungan atau situasi yang dihadapinya. Menurut Maslow (Iswidharmanjaya, 2004), percaya diri adalah modal dasar untuk pengembangan segala kemampuan diri sehingga mampu mengenal dan 
pengembangan potensi diri yang

memahami diri sendiri. Kurang percaya anak. Sehingga menunjukan sikap pesimis terhadap tantangan, takut dan ragu-ragu dalam menyampaikan gagasan, bimbang dalam menentukan pilihan dan sering membandingkan dirinya dengan orang lain.

\section{Token Economy}

Token economy adalah sebuah program behavior yang setiap individu akan memperoleh token atau tanda dari perilaku yang telah ditunjukan berdasarkan perilaku yang diinginkan dan dapat menukar penanda tersebut untuk memperoleh penguat pendukung (Martin dan Pear, 2015). Menurut Abramowiz dalam Mulyani (2013) mengatakan token economy merupakan suatu cara untuk menguatkan tingkah laku yang ditujukan seorang anak yang sesuai dengan target yang telah ditentukan dengan menggunakan hadiah (reward) untuk penguatan yang simbolik.

Menurut Doll, McLaughlin dan Barretto (2013) sistem pendidikan yang telah menggunakan metode token economy dinilai efektif sebagai sarana untuk mengelola perilaku anak di sekolah yang bertindak dan melayani
KUMARA CENDEKIA Vol. 7 No. 3 September 2019 dimiliki

diri dapat menghambat kemudian memberikan imbalan untuk perilaku tertentu yang telah ditargetkan. Sejalan dengan pendapat tersebut menurut Salmon (2015) token economy adalah sistem modifikasi perilaku yang digunakan oleh guru untuk memperkuat perilaku anak yang diinginkan melalui penguatan sistematis menggunakan satuan ukuran yang disebut token. Token sendiri adalah unit penguatan sistematis yang diberikan untuk meningkatkan perilaku anak yang diinginkan.

Selanjutnya menurut Alter, dkk (2008) juga mendefinisikan tentang token economy yang dapat digunakan sebagai strategi dalam mengelola kelas. Teknik token economy melibatkan aturan -aturan tertentu sebagai cara untuk memperoleh token dan menukarnya dengan hadiah. Sedangkan Omrod (2008), menyatakan bahwa token economy merupakan teknik ketika perilaku yang diinginkan muncul maka diberikan penguatan oleh token yang dapat digunakan anak untuk membeli berbagai penguat/reward yang lain.

\section{METODE}

Penelitian ini dilaksanakan di TK 
Marsudisiwi Jajar Surakarta.

Penelitian ini berlangsung selama 6 bulan Yaitu bulan Maret 2018 hingga bulan Agustus 2018. Subjek penelitian ini adalah anak usia 5-6 tahun dengan jumlah 14 anak, terdiri dari 8 anak laklaki dan 6 anak perempuan.

Data dalam penelitian ini berupa data kuantitatif yaitu hasil penilaian percaya diri menggunakan skala psikologi dan data kualitiatif berupa hasil observasi dan wawancara. Sumber data diperoleh dari anak usia 5-6 tahun, guru yang mengajar, hasil aktivitas pembelajaran anak usia 5-6 tahun, arsip dan dokumen selama program semester, serta video atau foto selama proses pembelajaran. Teknik pengumpulan data kuantitatif maupun kualitatif menggunakan teknik pengamatan observasi, wawancara, dokumentasi, dan tes. Uji validitas data kualitatif penelitian ini menggunakan triangulasi sumber dan triangulasi teknik pengumpulan data, sedangkan uji validitas data kuantitatif menggunakan validitas konstruk. Analisis data dalam penelitian ini menggunakan teknik analisis kuantitiatif berupa teknik analisis data statistik deskriptif untuk menganalisis data dengan cara
KUMARA CENDEKIA Vol. 7 No. 3 September 2019 mendeskripsikan atau menggambarkan data yang telah terkumpul, serta teknik analisis kualitatif yaitu menggunakan model interaktif dengan tahapan yaitu pengumpulan data, reduksi data, tampilan data, dan penarikan kesimpulan.

Penelitian ini dilaksanakan selama dua siklus, setiap siklus terdiri dari dua kali pertemuan atau tatap muka dengan prosedur pelaksanaan penelitian yang terdiri dari 4 tahapan yaitu perencanaan (planning), pelaksanaan tindakan (action), observasi (observation), dan refleksi (reflection).

Penialian menggunakan skor 1 untuk anak yang dinilai belum berkembang sesuai indikator, skor 2 untuk anak yang dinilai kurang berkembang sesuai indikator, skor 3 untuk anak yang dinilai mampu berkembang sesuai indikator.

\section{HASIL DAN PEMBAHASAN}

Penelitian ini dilaksanakan selama dua siklus, setiap siklus terdiri dari empat kali pertemuan. Pelaksanaan tindakan menggunakan penerapan metode token economy, sedangkan untuk observasi menggunakan skala psikologi berdasarkan indikator konsentrasi percaya diri anak. 


$$
\text { Pelaksanaan penelitian ini }
$$

dimulai dengan perencanaan yaitu 1)

dan bahan penelitian; 3) menyiapkan lembar observasi berupa skala psikologi percaya diri anak; dan 4) menyiapkan

kelengkapan peralatan dokumentasi.

Peneliti dalam penelitian ini berperan sebagai observator dan konsepsor sedangkan guru bertugas dalam proses pelaksanaan.

Analisis terhadap hasil observasi dilakukan terhadap ketercapaian hasil nilai percaya diri anak tiap skor indikator. Hal ini bertujuan untuk mengetahui peningkatan setiap skor indikator pada setiap pertemuan, karena anak yang mendapatkan ketuntasan secara klasikal belum tentu mampu memiliki kemampuan yang sama dalam semua indikator percaya diri. Indikator tersebut antara lain: yaitu 1) maju kedepan kelas untuk menunjukan

karya/kemampuannya;

mengungkapkan respon (pertanyaan/tanggapan) terhadap materi yang diberikan guru; 3) menjawab
KUMARA CENDEKIA Vol. 7 No. 3 September 2019 menyusaun RPPH bersama guru; 2) menyiapkan alat

Tabel 1. Analisis data ketercapaian skor percaya diri anak dari pra tindakan, siklus I, dan siklus II

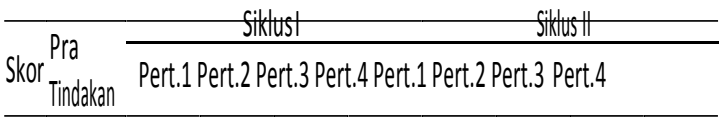

$135,71 \% 26,79 \% 17,86 \% 12,50 \%$ 7,14\% 3,57\% 3,57\% 3,57\% $1,79 \%$

$246,43 \% 55,36 \% 662,50 \% 64,29 \% 66,07 \% 62,50 \% 62,50 \% 55,36 \% 553,57 \%$

$317,86 \% 17,86 \% 19,64 \% 23,21 \% 26,79 \% 33,93 \% 33,93 \% 411,07 \% 44,64 \%$

Berdasarkan tabel 1, dapat disajikan dalam histogram pada Gambar 1 sebagai berikut:

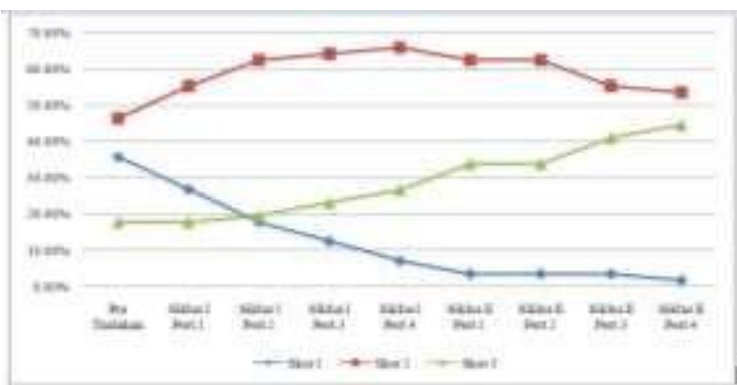

Gambar 1. Histogram Ketercapaian percaya diri anak tiap skor indikator. 
Tabel 2. Analisis data klasikal ketercapaian percaya diri anak dari pra pertanyaan yang diajukan guru; dan 4)

menyelesaikan tugas/aktivitas sesuai dengan intruksi yang diberikan guru secara mandiri. Berikut hasil dari penelitian yang telah dilaksanakan:

Berdasarkan tabel 2, dapat disajikan dalam histogram pada Gambar 2 sebagai berikut :

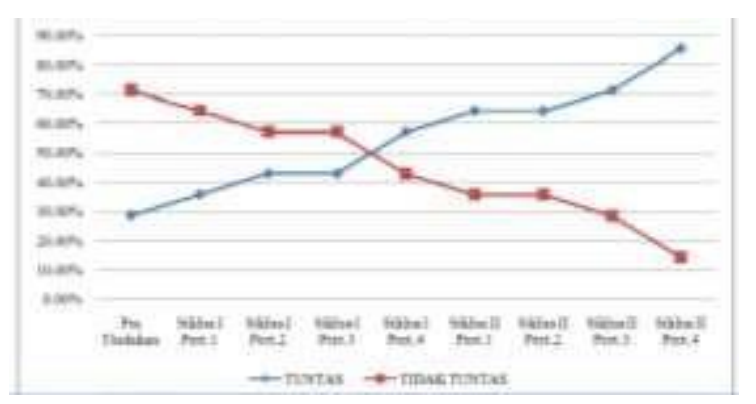

Gambar 2. Histogram

Ketercapaian percaya diri anak secara klasikal

Berdasarkan tebel diatas dapat dijelaskan bahwa pada data hasil pra tindakan ketuntasan klasikal di kelas B TK Marsudisiwi tahun ajaran 2017/2018 menunjukan peningkatan yang positif setelah adanya penerapan metode token economy di kelas tersebut. Hasil rata-rata ketercapaian skornya pada saat pra tindakan menunjukan hasil pada skor 1 sebesar $35,71 \%$, skor 2 sebesar $46,43 \%$, dan
KUMARA CENDEKIA Vol. 7 No. 3 September 2019 tindakan, siklus I, dan siklus II

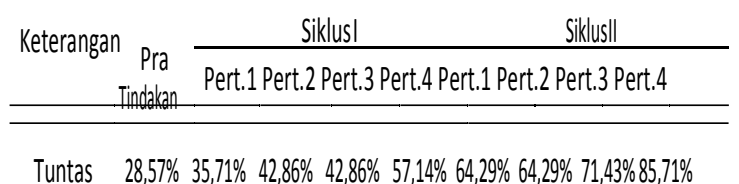

TidakTuntas 71,43\% 64,29\% 57,14\% 57,14\% 42,86\% 35,71\% 35,71\% 28,57\% 14,29\%

$17,86 \%$ pada skor 3 . Sedangkan hasil rata-rata ketuntasan percaya diri anak menunjukan hasil sebesar 28,57 \% di kelas tersebut yang dapat dikatakan tuntas sedangkan yang lainnya sebesar $71,43 \%$ dikatakan tidak tuntas, sedangkan. Setelah di terapkannya metode token economy pada siklus I pertemuan 1 diperoleh hasil rata-rata ketercapaian tiap skornya sebesar $26,79 \%$ pada skor 1 , skor 2 sebesar

$55,36 \%$, dan $17,86 \%$ pada skor 3 , sedangkan untuk hasil ketuntasan klasikalnya sebesar $35,71 \%$ anak dikatakan tuntas hal ini berarti ada peningkatan sebesar $7,14 \%$ sehingga presentase ketidak tuntasan menurun menjadi 71,43\%. Kemudian pada siklus I pertemuan 2 diperoleh hasil rata-rata ketercapaian tiap skornya sebesar $17,86 \%$ pada skor 1 , skor 2 sebesar $62,50 \%$, dan 
19,64\% pada skor 3, sedangkan tingkat ketuntasan meningkat lagi sebesar $7,15 \%$ menjadi $42,86 \%$ dan menurunkan presentase ketidak tuntasan menjadi 57,14\%.

\section{Peningkatan tersebut} menunjukan hasil yang positif dilanjutkan pada siklus I pertemuan 3 ini diperoleh hasil rata-rata ketercapaian tiap skornya sebesar $12,50 \%$ pada skor 1 , skor 2 sebesar $64,29 \%$, dan $23,21 \%$ pada skor 3 , namun pada hasil rata-rata klasikalnya siklus 1 pertemuan 3 tidak mengalami peningkatan atau dapat dikatakan hasilnya masih sama seperti pada pertemuan 2. Sedagkan pada pertemuan 4 diperoleh hasil rata-rata ketercapaian tiap skornya sebesar $7,14 \%$ pada skor 1 , skor 2 sebesar $66,07 \%$, dan

26,79\% pada skor 3 dan hasil penilaian klasikla percaya diri anak mengalami peningkatan yang cukup baik sebesar 14,28\% menjadi $57,14 \%$ setelah sebelumnya pada pertemuan 2 menuju 3 1 baik hasil rata-rata ketercapaian tiap skornya maupun tingkat ketuntasan klasikalnya. Kemudian pada pertemuan 3 diperoleh hasil rata-rata ketercapaian tiap skornya sebesar tidak meningkat hal ini menurunkan presentase ketidak tuntasan menjadi $42,86 \%$. Setelah dilaksanakannya 4 kali pertemuan diketahui bahwa tingkat ketuntasan percaya diri anak hanya sebesar 57,14\% dan hasil ini masih terlalu jauh dari target yang telah ditetapkan peneliti sebelumnya sehingga peneliti memutuskan untuk melanjutkan penelitian pada siklus II.

Pada siklus II yang telah dilaksanakan dapat di amati bahwa diperoleh hasil rata-rata ketercapaian tiap skornya sebesar $3,57 \%$ pada skor 1 , skor 2

sebesar $62,50 \%$, dan $33,93 \%$ pada skor 3 sedangkan tingkat ketuntasan percaya diri anak mengalami peningkatan setelah pada siklus I petemuan 4 sebelumnya sebesar 42,86\% kini pada siklus II pertemuan 1 ini meningkat sebesar $7,15 \%$ menjadi $64,29 \%$ dan menurunkan presentase ketidak tuntasan menjadi $35,71 \%$. Namun pada siklus II petemuan 2 menunjukan hasil yang masih sama pada siklus II pertemuan

$3,57 \%$ pada skor 1 , skor 2 sebesar 55,36\%, dan 33,93\% pada skor 3 sedangkan hasil ketuntasan klasikal meningkat lagi sebesar 7,14\% menjadi 
$71,43 \%$, hasil ini menunjukan bahwa pada siklus II pertemuan 3 hasilnya semakin dekat dengan target yang sebelumnya telah peneliti tetapkan. Akhirnya pada siklus II pertemuan 4 menunjukan hasil rata-rata ketercapaian tiap skornya sebesar $1,79 \%$ pada skor 1 , skor 2 sebesar $53,57 \%$, dan

44,64\% pada skor 3 dan ketuntasan percaya diri anak sebesar $85,71 \%$ yang berarti ini telah meningkat sebesar 14,28\% dibandingkan pada

pertemuan

sebelumnya. Ketuntasan sebesar $85,71 \%$ pada akhir siklus II ini telah melebihi dari target yang ditetapkan peneliti sebelumnya sehingga hasil ini dapat

Hasil penelitian menunjukkan bahwa penerapan metode token economy dapat menjadi upaya meningkatkan percaya diri anak. Hal tersebut sesuai dengan pendapat Salmon (2015) yang menyatakan bahwa metode token economy dapat mengubah perilaku anak secara sistematis dengan memberikan token sebagai penguat perilaku apabila anak memperlihatkan perilaku yang diinginkan tersebut dalam hal ini perilaku anak yang
KUMARA CENDEKIA Vol. 7 No. 3 September 2019 dimaksud adalah percaya diri. Hasil penelitian menunjukkan bahwa penerapan metode token economy dapat meningkatkan percaya diri anak dalam proses pembelajaran. Hal tersebut dikarenakan dengan menerapkan metode token economy yang didalam metode tersebut terdapat reward yang akan diteriman anak ketika anak mampu memperoleh banyak token yang didapatkan anak ketika menunjukan perilaku-perilaku percaya diri sesuai dengan indikator yang telah di tentukan peneliti maka percaya diri anak akan muncul dengan sendirinya setelah timbulnya motivasi dalam diri anak yang ingin memperoleh reward.

\section{KESIMPULAN}

Berdasarkan hasil penelitian dan pembahasan, maka dapat disimpulkan bahwa metode token economy yang diterapkan pada anak usia 5-6 tahun dalam proses pembelajaran mampu meningkatkan percaya diri (self confidence) anak yang meliputi, 1) maju kedepan kelas untuk menunjukan karya/kemampuannya; 2) mengungkapkan

respon (pertanyaan/tanggapan) terhadap materi yang diberikan guru; 3) menjawab pertanyaan yang diajukan guru; dan 4) menyelesaikan tugas/aktivitas sesuai 
dengan intruksi yang diberikan guru secara mandiri.

Metode token economy mampu meningkatkan percaya diri anak dengan memberikan token yang akan diberikan kepada anak ketika anak memperlihatkan perilaku-perilaku percaya diri sesuai dengan indikator yang telah dirumuskan. Token berupa bintang kemudian dikumpulkan dengan ditempel pada papan nama anak masing-masing. Kemudian pada akhirnya token yeng telah terkumpul akan ditukar dengan reward yang perlu merefleksi situasi yang sedang berjalan dan mengajak anak untuk semangat dalam mengumpulkan token.

\section{DAFTAR PUSTAKA}

Al-Hebaish, S.M. (2012) . The Correlation between General Self-Confidence and Academic Achievement in the Oral Presentation Course. Theory and Practice in Language Studies,2 (1) 60-65 ISSN 1799 -

2591. Diperoleh pada 8 Maret 2018, dari https://pdfs. semanticscholar.org/8587/88713ff 814495c8315bd22ff74681d9032a3 .pdf

Alter, P.J., dkk. (2008). Improving Mathenatics Problem Solving Skill ISSN 2301-8038. th Challenging Behavior. Beyond Behavior, 17(3) 2-7. ISSN-1074-2956 Diperoleh pada 13 Maret 2018, dari
KUMARA CENDEKIA Vol. 7 No. 3 September 2019 dapat anak sesuai dengan jumlah token yang dimiliki. Reward yang diterima anak inilah yang akan memotivasi anak untuk lebih aktif dalam setiap kegiatan pembelajaran sehingga percaya diri anak akan meningkat. Pelaksanaan kegiatan tersebut diserahkan kepada guru dengan langkah- langkah seperti pembelajaran biasa. Hanya saja guru harus lebih aktif dalam memonitor anak dan memberikan perhatian pada seluruh anak secara merata. Partisipasi anak yang aktif akan sangat membantu proses pembelajaran, guru juga

https://eric.ed.gov/?id=EJ894098

$\begin{array}{crr}\text { Dariyo, A. (2007). } & \text { Psikologi } \\ \text { Perkembangan Tiga } & \text { Tahun } \\ \text { Pertama. } \quad \text { Bandung: } & \text { Refika } \\ \text { Aditama } & & \end{array}$

Dirjen PAUDNI. (2012). Pedoman Pendidikan Karakter Pada Anak Usia Dini. 1-41. Jakarta: Direktorat Jendral Pendidikan Anak Usia Dini. Diperoleh pada 18 April 2018, dari perpustakaan online kemdikbud di http://repositori. perpustakaan.kemdikbud.go.id/617 4/1.pdf

Doll, C., McLaughlin, T.F., dan Barretto, A. (2013). The Token Economy: A Recent Review and Evaluation. International Journal of Basic and Applied Science, 2 (01) 131-14.

Diperoleh pada 2018,

dar 
https://pdfs.semanticscholar.org $/ 18$

70/ad57056432dd3ddb7873387

956

9e213bab13.pdf

Iswidharmanjaya. (2004). Suatu Hari Menjadi Lebih Percaya Diri. Jakarta: Elex Media Komputindo

Lauster, P. (2006). Tes Kepribadian. Ahli Bahasa : D.H Gulo. Edisi Bahasa Indonesia. Jakarta : Bumi Aksara

Martin, Garry. Pear, J. (2015). Modifikasi Perilaku:

\section{Makna}

dan

Penerapannya. Terj. Edi Purwanta. Yogyakarta: Pustaka Pelajar.

Mulyani, R.R. (2013). Penerapan token ekonomi untuk meningkatkan atensi dalam mengerjakan tugas pada anak ADHD. Jurnal Sains dan Praktik Psikologi. UMM. 1(1). Diperoleh pada 13 Maret 2018, dari http://ejournal.umm.ac.id /index.php/jspp/article/view/13 $43 / 1438$

Omrod, Jeanne Ellis. (2009). Psikologi Pendidikan Membantu Anak Tumbuh dan Berkembang. Terj. Wahyu Indianti. Jakarta: Erlangga

Rahayu, A.Y. (2013). Menumbuhkan Kepercayaan Diri Melalui Kegiatan Bercerita. Jakarta: PT. Indeks

Salmon, Raul Dennis. (2015). The Effect Of A Classroom Token Economy On Students' Academic. Performance. Classroom Token Economie. 61-683. Diperoleh pada 13 Maret 2018, dari Department of Professional Education Faculty Northwest Missouri State University

ouri Miss

http://www.nwmissouri.edu/libr ary /ResearchPapers/2015/Salmon, $\% 2$ 0Raul.pdf 
KUMARA CENDEKIA Vol. 7 No. 3 September 2019 